\title{
Yoghurt kedelai hitam (black soyghurt) dapat menurunkan kadar LDL tikus hiperkolesterolemia
}

\author{
Black soyhghurt decreased the LDL serum of hypercholesterolemic rats
}

Slamet Riyanto ${ }^{1}$, Hesti Muwarni $R^{2}$

\begin{abstract}
Background: Hypercholesterolemia is a main risk factor of cardiovascular disease that remains the higher cause of deaths in the world. Black soy bean containing protein, fiber, vitamin, isoflavon, and flavonoid can decrease serum cholesterol level. Yoghurt contains lactic acid bacteria that decrease total and LDL cholesterol, triglyceride, and increase the HDL cholesterol. Processing of black soy bean into black soyghurt can increase its isoflavon's activity by forming aglicone, which has higher activity to decrease cholesterol.

Objectives: To know the effect of black soyghurt feeding to $L D L, H D L$, and $H D L$ ratio of hypercholesterolemic rats.

Methods: This research was true-experimental using post test only with control group design. Subjects were 20 male Sprague dawley rats, 2 months old, inducted hypercholesterolemia, given black soyghurt diet using $2 \mathrm{~mL}, 3 \mathrm{~mL}$, and $4 \mathrm{~mL}$ dosage for 21 days. Serum lipid profile were measured by CHOD-PAP and GPO-PAP methods respectively. Normality of the data were tested by Shapiro Wilks test. Data were analyzed by paired t test and Anova continued by LSD test using computer program.

Results: The study revealed that black soyghurt $4 \mathrm{~mL} /$ day decreased $L D L(p=0.02)$ at the most significant level. The other doses did not significantly influence the levels of $L D L(p>0.05)$. There was also no effect of black soyghurt feeding on serum HDL cholesterol levels $(p=0.11)$ and the ratio of $L D L / H D L(p=0.087)$. Conclusions: The feeding of black soyghurt at th dosage of $4 \mathrm{~mL} /$ day to hypercholesterolemic rats could decrease the serum LDL, but could decrease the ratio of LDL / HDL significantly.
\end{abstract}

KEYWORDS: black soyghurt, LDL/HDL ratio, hypercholesterolemic

\begin{abstract}
ABSTRAK
Latar belakang: Hiperkolesterolemia merupakan faktor risiko penyakit kardiovaskuler yang menjadi penyebab kematian utama di dunia. Kedelai hitam mengandung protein, vitamin, serat, isoflavon, dan flavonoid yang mampu menurunkan kadar kolesterol. Yoghurt mengandung bakteri asam laktat yang mampu menurunkan kadar kolesterol total, LDL, dan trigliserida serta meningkatkan HDL. Pengolahan kedelai hitam menjadi black soyghurt meningkatkan aktivitas isoflavon dalam kedelai hitam menjadi aglikon yang lebih tinggi aktivitasnya dalam menurunkan kolesterol.

Tujuan: Untuk mengetahui pengaruh pemberian yoghurt kedelai hitam terhadap kadar LDL, HDL, dan rasio $L D L / H D L$ pada tikus hiperkolesterolemia.

Metode: Jenis penelitian ini adalah true-experimental dengan post test only with control group design. Subjek penelitian adalah 20 tikus Sprague dawley jantan berusia 2 bulan, diinduksi hiperkolesterolemia, diberi black soyghurt dosis $2 \mathrm{~mL}, 3 \mathrm{~mL}$, dan $4 \mathrm{~mL}$ selama 21 hari. Profil lipid diperiksa dengan metode cholesterol oxidase-peroxidase aminoantipyrine phenol (CHOD-PAP). Normalitas data diuji dengan Shapiro Wilks. Data dianalisis dengan uji t berpasangan dan Anova, dilanjutkan uji least significant difference (LSD) menggunakan program komputer.
\end{abstract}

\footnotetext{
${ }^{1}$ Balai Penelitian GAKI Magelang. Balitbang Kemenkes, Kavling Jaya, Borobudur, Magelang, e-mail: semangat_riyanto@yahoo. co.id

2 Program Studi IImu Gizi Fakultas Kedokteran Universitas Diponegoro, Jl. Dr. Sutomo No. 14 Semarang
} 
Hasil: Pemberian black soyghurt dosis $4 \mathrm{~mL}$ /hari mampu menurunkan kadar $L D L(p=0,002)$ paling signfikan. Dosis pemberian lain tidak berpengaruh secara signifikan terhadap kadar $L D L(p>0,05)$. Pemberian pakan tersebut juga tidak berpengaruh terhadap kadar kolesterol HDL serum hewan coba $(p=0,11)$, dan rasio LDL/HDL $(p=0,087)$.

Kesimpulan: Diet mengandung black soyghurt dosis $4 \mathrm{~mL} /$ hari dapat menurunkan $L D L$, tetapi tidak mampu menurunkan rasio $L D L / H D L$ secara signifikan.

KATA KUNCI: black soyghurt, rasio LDL/HDL, hiperkolesterolemia

\section{PENDAHULUAN}

Penyakit kardiovaskuler merupakan penyebab kematian utama negara-negara berkembang di dunia. Separuh dari seluruh kematian di Amerika Utara disebabkan penyakit kardiovaskuler (1). Berdasarkan Survei kesehatan rumah tangga (SKRT) menunjukkan bahwa proporsi kematian akibat penyakit kardiovaskuler di Indonesia semakin meningkat yaitu 9,75\% (tahun 1985), 16,4\% (tahun 1992), 19,8\% (tahun 1995), dan menjadi $26,3 \%$ (tahun 2001). Berdasarkan data SKRT tahun 2005, kematian akibat penyakit ini tidak hanya terjadi pada orang dewasa, akan tetapi juga pada usia kurang dari 20 tahun (2).

Hiperkolesterolemia merupakan salah satu faktor risiko terjadinya penyakit kardiovaskuler. Kadar kolesterol yang meningkat dapat menyebabkan penyempitan pembuluh darah atau aterosklerosis (3). Untuk menghindari penyakit tersebut, dibutuhkan pengendalian kadar kolesterol darah secara tepat. Salah satu cara yang aman untuk menurunkan kadar kolesterol darah adalah dengan modifikasi diet. Secara umum, diet yang dianjurkan adalah dengan membatasi konsumsi makanan yang mengandung kolesterol dan lemak terutama lemak jenuh yang tinggi (4). Diet ini memberikan efek yang lebih aman, sehingga sangat dianjurkan sebelum memutuskan terapi dengan menggunakan obat-obatan. Selain membatasi konsumsi kolesterol dan lemak, untuk menurunkan kadar kolesterol juga dianjurkan untuk mengonsumsi jenis-jenis bahan makanan yang memiliki efek antihiperkolesterolemia seperti kedelai hitam (5).

Sebuah metaanalisis terhadap 38 uji klinis menyimpulkan bahwa protein pada kacang kedelai mampu menurunkan kadar kolesterol total sebesar $3,8-9,3 \%$, trigliserida $5,3-12,9 \%$, dan mampu meningkatkan kadar HDL kolesterol sebesar 2,4-3\% (6). Selain itu, kulit dari kedelai hitam merupakan sumber pigmen antosianin seperti cyanidin-3-glucoside dan delphinidin-3-glucoside yang dapat menurunkan kadar kolesterol darah. Kandungan antosianin pada kedelai hitam jauh lebih banyak dibanding kedelai kuning karena warna hitam pada kulitnya (7).

Black soyghurt merupakan produk fermentasi susu kedelai hitam oleh bakteri asam laktat. Produk olahan kedelai hitam baik yang diolah secara fermentasi ataupun non-fermentasi akan memiliki aktivitas zat bioaktif yang lebih tinggi daripada kedelai hitam tanpa pengolahan. Proses pengolahan akan menghidrolisis senyawa isoflavon menjadi senyawa isoflavon bebas yang disebut aglikon yang lebih tinggi aktivitasnya (8). Selain itu berdasarkan penelitian sebelumnya menyebutkan bahwa bakteri asam laktat berpotensi menurunkan kadar kolesterol darah karena bakteri dalam produk tersebut menghasilkan asamasam organik seperti asam propionat dan asam laktat yang dapat berperan sebagai agen penurun kadar kolesterol darah (9).

Beberapa hasil penelitian menunjukkan bahwa rasio LDL/HDL merupakan prediktor terbaik untuk mengetahui risiko penyakit jantung koroner dibanding hanya kolesterol LDL atau kolesterol HDL sendiri. Selain itu, penelitian mengenai yoghurt kedelai hitam dan pengaruhnya terhadap rasio LDL/ HDL serum tikus hiperkolesterolemia belum pernah dilakukan. Melalui penelitian ini, dikaji lebih jauh mengenai pengaruh pemberian pemberian yoghurt kedelai hitam (black soyghurt) terhadap rasio LDL/ HDL tikus hiperkolesterolemia.

\section{BAHAN DAN METODE}

Penelitian ini berjenis true experiment dengan post test only with control group design. Perlakuannya 


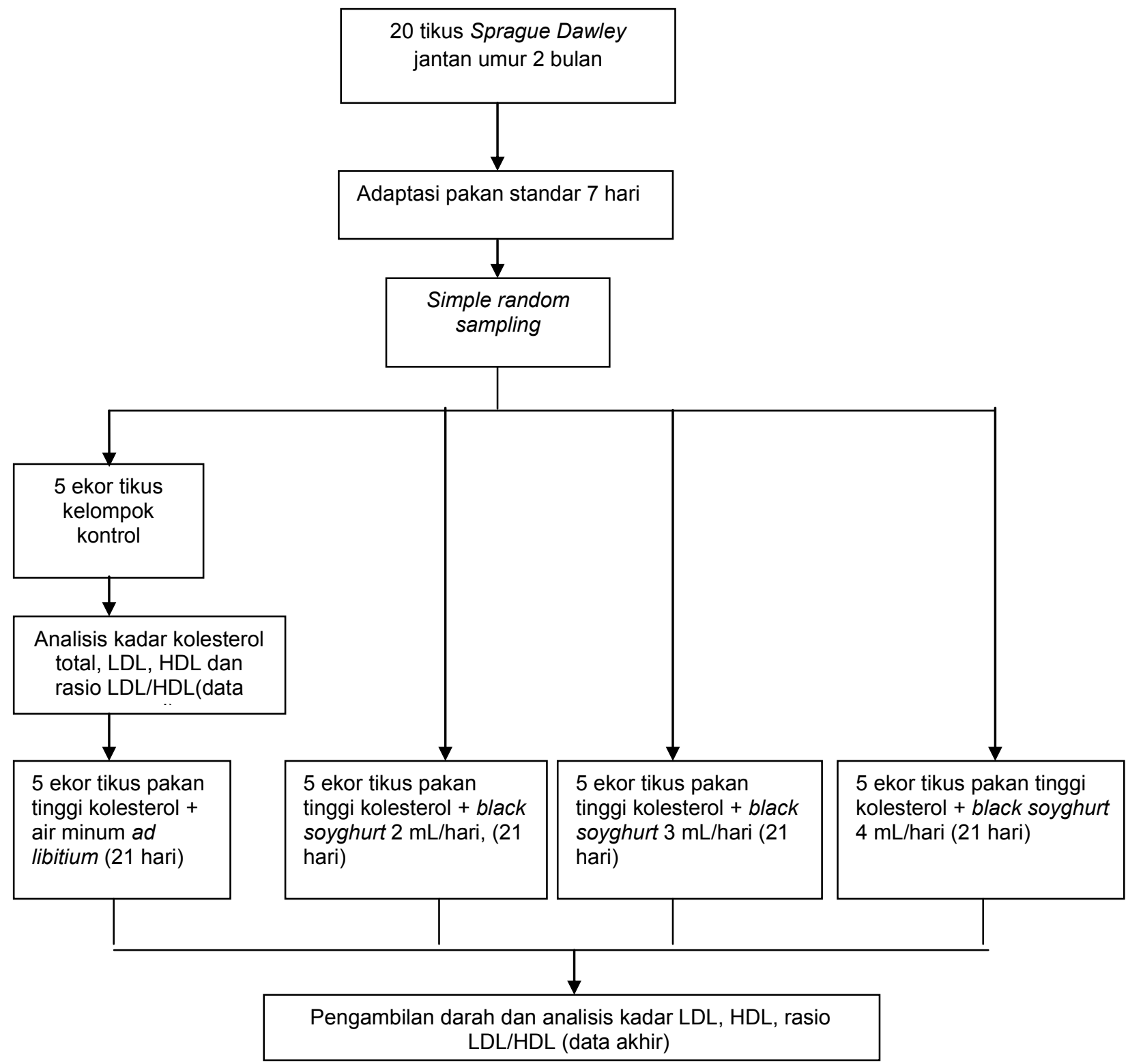

Gambar 1. Bagan alur penelitian

adalah dengan pemberian yoghurt kedelai hitam (black soyghurt), sedangkan keluarannya (outcome) adalah kadar LDL (low density lipoprotein), HDL (high density lipoprotein) dan rasio LDL/HDL.

Subjek penelitian yang digunakan adalah tikus jantan galur Sprague dawley umur 2 bulan yang diperoleh dari Unit Pengembangan Hewan Percobaan (UPHP) Universitas Gadjah Mada, Yogyakarta. Tikus yang diperoleh kemudian dikandangkan dengan siklus pencahayaan $12 \mathrm{jam}$. Tikus mendapat makan dan minum ad libithum.
Penentuan jumlah subjek menggunakan ketentuan WHO dengan jumlah minimal subjek per kelompok adalah 5 subjek (10). Pada penelitian ini, terdapat tiga kelompok perlakuan dan satu kelompok kontrol. Kelompok pertama diberi perlakuan pakan tinggi kolesterol dan black soyghurt $2 \mathrm{~mL}$, kelompok kedua diberi perlakuan pakan tinggi kolesterol dan black soyghurt $3 \mathrm{~mL}$, kelompok ketiga diberi perlakuan pakan tinggi kolesterol dan black soyghurt $4 \mathrm{~mL}$ dan perlakuan pakan tinggi kolesterol saja pada kelompok kontrol. Oleh karena itu, pada 
penelitian ini dibutuhkan minimal 20 ekor tikus jantan galur Sprague dawley.

Seluruh subjek diadaptasi terlebih dahulu selama 7 hari dan diberi pakan standar rodentia dan minum air ad libithum. Selanjutnya, subjek diberi pakan tinggi kolesterol dan hanya pada kelompok perlakuan diberikan black soyghurt dengan dosis yang berbeda. Pemberian pakan tinggi kolesterol pada kelompok kontrol dan pakan tinggi kolesterol dan black soyghurt dengan berbagai dosis pada kelompok perlakuan dilakukan selama 21 hari. Pakan tinggi kolesterol yang diberikan adalah berupa otak sapi yang telah dikukus dan diblender dengan dosis $2 \mathrm{~mL} /$ hari untuk menginduksi hiperkolesterolemia. Black soyghurt yang digunakan merupakan yoghurt berbahan dasar susu kedelai hitam lokal dengan jumlah bakteri $10^{7-8} \mathrm{CFU} / \mathrm{mL}$. Pembuatan black soyghurt mengacu pada penelitian sebelumnya dengan menambahkan starter berupa Lactobacillus casei dan Streptococcus thermophilus sebanyak $10 \%$ dengan perbandingan $1: 1$ sehingga dihasilkan yoghurt dengan $\mathrm{pH}$ asam yaitu 4-5 dan memiliki aktivitas antioksidan yang tinggi (8).

Dosis pemberian black soyghurt didasarkan pada dosis anjuran untuk susu fermentasi bagi manusia dengan berat badan $70 \mathrm{~kg}$ yaitu sekitar 100-200 mL/hari. Dosis ini kemudian dikonversi dengan dosis untuk tikus dengan berat badan $200 \mathrm{~g}$, sehingga didapatkan dosis pemberian $2 \mathrm{~mL}, 3 \mathrm{~mL}$, dan $4 \mathrm{~mL}$ per $200 \mathrm{~g}$ berat badan tikus. Pemberian pakan tinggi kolesterol dan black soyghurt dilakukan dengan sonde. Penentuan subjek setiap kelompok dilakukan dengan simple random sampling.

Kadar kolesterol total, LDL, HDL, serta rasio LDL/HDL awal hanya dianalisis pada kelompok kontrol saja, kemudian data kadar LDL, HDL, dan rasio LDL/HDL akhir didapatkan dari semua kelompok perlakuan selama 21 hari. Sampel darah diambil dari plexus pre-orbitalis tikus Sprague dawley sebanyak 150-250 $\mu \mathrm{L}$ dan dimasukkan ke dalam tabung bersih, kemudian darah disentrifuge untuk mendapatkan serumnya. Kadar kolesterol total, HDL, dan LDL serum darah tikus diperiksa dengan metode CHO-PAP dan glycerol-3-phospate peroxidase aminoantipyrine phenol (GPO-PAP). Sedangkan rasio LDL/HDL merupakan perbandingan kadar LDL terhadap kadar HDL.

Data yang diperoleh diolah dengan program komputer. Data tersebut diuji normalitasnya dengan uji Saphiro Wilks. Perbedaan kadar kolesterol total, LDL dan HDL serum serta rasio LDL/HDL sebelum dan sesudah pemperian pakan tinggi kolesterol pada kelompok kontrol di uji dengan paired t-test. Perbedaan pengaruh dari keempat kelompok perlakuan dianalisis menggunakan uji statistik parametrik Anova, kemudian dilanjutkan dengan uji $L S D$ pada tingkat kepercayaan 95\%. Penelitian ini telah mendapatkan persetujuan dari Komisi Etik Penelitian Kesehatan (KEPK) FK Undip dan RSUP dr Kariadi Semarang berdasarkan ethical clearance nomor 078/EC/FK/RSDK/2011.

Pemeliharaan hewan percobaan dilakukan di Laboratorium Biologi FMIPA Universitas Negeri Semarang. Pemeriksaan profil lipid dilakukan di Laboratorium Kesehatan Jawa Tengah.

\section{HASIL}

\section{Profil lipid setelah pemberian pakan tinggi kolesterol}

Gambaran perubahan profil lipid setelah pemberian pakan tinggi kolesterol selama 21 hari dapat dilihat pada Tabel 1 dan Tabel 2.

Berdasarkan data pada Tabel 1, terlihat bahwa terjadi peningkatan secara signifikan kadar

Tabel 1. Perbedaan profil lipid kelompok kontrol sebelum dan setelah pemberian pakan tinggi kolesterol $(n=5)$

\begin{tabular}{|c|c|c|c|c|}
\hline \multirow{2}{*}{ Profil lipid } & \multicolumn{2}{|c|}{ Rerata (mg/dL) } & \multirow{2}{*}{$\%$ perubahan } & \multirow[b]{2}{*}{$\mathbf{p}$} \\
\hline & Sebelum & Sesudah & & \\
\hline Kolesterol total & $41,02 \pm 7,92$ & $70,10 \pm 13,29$ & 71,00 & $0,03^{*}$ \\
\hline LDL & $25,31 \pm 4,00$ & $39,17 \pm 11,07$ & 54,70 & $0,03^{*}$ \\
\hline HDL & $14,16 \pm 3,60$ & $15,30 \pm 5,78$ & 8,00 & 0,72 \\
\hline Rasio LDL/HDL & $1,97 \pm 0,91$ & $2,71 \pm 0,72$ & 37,56 & 0,17 \\
\hline
\end{tabular}

*Signifikan $(p<0,05)$ 
kolesterol total dan LDL, tetapi tidak disertai dengan perubahan kadar HDL.

\section{Profil lipid setelah intervensi dengan black soyghurt}

Kadar profil lipid pada kelompok perlakuan diukur setelah 21 hari masa intervensi. Data profil lipid antarkelompok perlakuan yang didapat kemudian dianalisis perbedaanya dengan menggunakan uji statistik Anova yang kemudian dilanjutkan dengan uji LSD. Gambaran hasil uji dapat dilihat pada Tabel 2.

Berdasarkan Tabel 2, diketahui bahwa pemberian dosis $4 \mathrm{~mL} /$ hari mampu menurunkan kadar LDL ( $p=0,002, p<0,05)$. Dosis pemberian lain tidak berpengaruh secara signifikan terhadap kadar LDL ( $p>0,05)$. Pemberian pakan tersebut juga tidak berpengaruh terhadap kadar kolesterol HDL serum hewan coba $(p=0,11)$ rasio $L D L / H D L(p=0,087)$.

\section{BAHASAN}

\section{Profil lipid setelah pemberian pakan tinggi kolesterol}

Berdasarkan data pada Tabel 1, terlihat bahwa terjadi peningkatan secara bermakna kadar kolesterol total dan LDL. Meskipun demikian, hal ini tidak disertai dengan perubahan kadar HDL secara signifikan. Rasio LDL/HDL mengalami kenaikan dibanding sebelum pemberian pakan tinggi kolesterol akan tetapi tidak signifikan berdasarkan statistik. Kenaikan kadar kolesterol total secara signifikan menunjukkan bahwa sampel telah mengalami hiperkolesterolemia.
Peningkatan kadar kolesterol total dan LDL disebabkan tingginya kadar kolesterol dan asam lemak jenuh yang terkandung dalam otak sapi. Dalam $100 \mathrm{~g}$ otak sapi, mengandung sekitar $2 \mathrm{~g}$ kolesterol dan 2,9 g asam lemak jenuh. Kolesterol yang ada di dalam tubuh dapat berasal dari asupan dan juga dari sintesis kolesterol oleh tubuh sendiri. Asupan kolesterol yang tinggi dapat meningkatkan kadar kolesterol dalam darah.

Selain itu, asam lemak jenuh dapat meningkatkan kadar LDL melalui mekanisme penurunan sintesis dan aktivitas reseptor LDL (11). Pada sebuah penelitian yang meneliti asupan lemak jenuh, PUFA (poly unsaturated fatty acid) dan kolesterol terhadap respon kadar kolesterol, setiap asupan lemak jenuh $1 \%$ dari total energi sehari diprediksi dapat meningkatkan 2,7 mg/dL kadar plasma kolesterol (12).

Pengaruh asupan kolesterol dan asam lemak jenuh terhadap kadar HDL dalam darah berdasarkan hasil penelitian sampai saat ini hasilnya masih diperdebatkan. Hal ini dimungkinkan karena kolesterol HDL kadarnya di dalam serum lebih dipengaruhi oleh faktor genetik (familial) dan juga jenis kelamin (13).

Berdasarkan data profil lipid, dapat disimpulkan bahwa kondisi hiperkolesterolemia juga terjadi pada kelompok perlakuan lain. Hal ini disebabkan pada kelompok non-kontrol juga diberi pakan tinggi kolesterol dengan dosis dan lama pemberian yang sama dengan kelompok kontrol. Hanya saja pada kelompok non-kontrol disertai dengan pemberian black soyghurt dengan dosis yang berbeda. Dengan demikian, pada penelitian ini dapat dilihat efek black soyghurt

Tabel 2. Rerata dan hasil uji Anova profil lipid antar kelompok perlakuan $(n=20)$

\begin{tabular}{|c|c|c|c|c|c|c|c|c|c|c|c|}
\hline & Sebelum & & Sesudah & & & $\Delta$ & & & $\% \Delta$ & & \\
\hline & P0 & P1 & P2 & P3 & P1 & P2 & P3 & P1 & P2 & P3 & $\mathbf{p}$ \\
\hline HDL & $15,3 \pm 5,8^{a}$ & $23,4 \pm 12,2^{\mathrm{a}}$ & $14,0 \pm 4,1^{\mathrm{a}}$ & $11,42 \pm 1,3^{a}$ & $8,1 \pm 15,1$ & $-1,4 \pm 7,2$ & $-3,9 \pm 5,6$ & 52,7 & 8,9 & 25,4 & 0,11 \\
\hline LDL & $39,2 \pm 11,1^{a}$ & $22,6 \pm 8,5^{b}$ & $29,4 \pm 6,0^{\mathrm{a}}$ & $17,13 \pm 5,3^{c}$ & $-16,6 \pm 16,6$ & $-9,8 \pm 14,9$ & $-22,0 \pm 13,3$ & 42,3 & 24,9 & 56,3 & $0,002^{*}$ \\
\hline Rasio LDL/HDL & $2,7 \pm 0,7^{a}$ & $1,3 \pm 1,0^{a}$ & $2,3 \pm 0,81^{a}$ & $1,53 \pm 0,6^{a}$ & $-1,4 \pm 1,3$ & $-2,2 \pm 1,0$ & $-1,2 \pm 0,9$ & 51,0 & 80,0 & 43,4 & 0,087 \\
\hline
\end{tabular}

P0 : kelompok kontrol (setelah diberi pakan tinggi kolesterol)

P1-3 : kelompok perlakuan 1-3 (pakan tinggi kolesterol+black soyghurt $2 \mathrm{~mL}, 3 \mathrm{~mL}$, dan $4 \mathrm{~mL}$ )

a, b, c : superskrip yang berbeda pada baris sama, berbeda bermakna $(p<0,05)$.

$\Delta \quad$ : selisih nilai parameter sebelum dan sesudah perlakuan (tanda negatif (-) menunjukkan adanya penurunan nilai)

$\% \Delta$ : persentase peningkatan atau penurunan nilai 
dalam menghambat ataupun mencegah terjadinya hiperkolesterolemia pada kelompok perlakuan dengan berbagai dosis pemberian.

\section{Profil lipid setelah intervensi dengan black soyghurt}

Tabel 2 menunjukkan adanya penurunan LDL pada semua perlakuan setelah pemberian black soyghurt selama 21 hari dan penurunan paling signifikan terjadi pada dosis $4 \mathrm{~mL}$. Meskipun demikian, berdasarkan uji statistik dapat diketahui bahwa pemberian black soyghurt pada semua dosis perlakuan tidak mampu menaikkan kadar kolesterol HDL dan menurunkan rasio LDL/HDL secara statistik.

Hasil penelitian ini mendukung hasil penelitianpenelitian sebelumnya terkait aktivitas bakteri asam laktat pada produk susu fermentasi ataupun aktivitas zat bioaktif pada kedelai terhadap profil lipid. Penelitian terdahulu menyebutkan bahwa pemberian yoghurt pada kelinci dengan dosis yang berbeda berturut-turut untuk kelompok $A$ (tanpa pemberian), B (2 mL), C (4 mL), dan D (6 $\mathrm{mL}$ ) yang diberikan selama lima hari menunjukkan terjadi penurunan kadar LDL pada kelompok yang diberikan yoghurt sebanyak $4 \mathrm{~mL}$ dan $6 \mathrm{~mL}$ secara signifikan (14). Sebuah metaanalisis juga menunjukkan bahwa protein pada kacang kedelai mampu menurunkan kadar kolesterol total sebesar 3,8-9,3\% dan trigliserida sebesar 5,3-12,9\% (6).

Mekanisme penurunanan kadar LDL antara lain dipengaruhi adanya bakteri asam laktat yang terdapat pada black soyghurt. Dalam black soyghurt mengandung kurang lebih $10^{7-8} \mathrm{CFU} / \mathrm{mL}$ bakteri asam laktat (8). Mekanisme penurunan kolesterol oleh bakteri ini di antaranya melalui mekanisme asimilasi kolesterol, dekonjugasi asam empedu, dan transformasi kolesterol menjadi kaprostanol.

Asimilasi kolesterol terjadi melalui mekanisme pengambilan kolesterol oleh bakteri asam laktat yang kemudian kolesterol tersebut akan berinkorporasi dengan membran sel bakteri sehingga menyebabkan berkurangnya jumlah kolesterol bebas yang ada di dalam tubuh (15). Beberapa penelitian yang telah dilakukan in vitro membuktikan adanya aktivitas asimilasi oleh bakteri asam laktat. Bakteri asam laktat yang digunakan adalah galur-galur dari spesies L. acidophilus, L. gasseri serta berbagai spesies lain, yaitu L. plantarum, L. sake, Streptococcus sp., dan Enterococcus $s p$. Sumber kolesterol yang digunakan bervariasi, baik berupa kolesterol murni, fraksi serum pleuro-pneumoniae like organism (PPLO), maupun misel kolesterol-fosfatidilkolin. Aktivitas asimilasi diamati dengan membandingkan jumlah kolesterol yang tersisa pada media yang diinokulasi dengan bakteri asam laktat dan kontrol (tidak diinokulasi bakteri). Hasil penelitian menunjukkan bahwa galur-galur yang diuji mempunyai aktivitas asimilasi kolesterol dengan derajat yang bervariasi dengan kisaran antara 8,2-83,3 $\mu \mathrm{g} / \mathrm{mL}$ (16).

Bakteri asam laktat juga diketahui mampu mensekresikan enzim bile salt hydrolase (BSH). Enzim ini akan memisahkan glisin atau taurin dari garam empedu terkonjugasi sehingga menghasilkan garam empedu bebas atau terdekonjugasi (17). Hal ini akan mengakibatkan asam empedu menjadi sulit diabsorbsi kembali dan didaur ulang melalui siklus enterohepatik, sehingga akan lebih banyak asam empedu yang diekskresikan melalui feses. Kondisi ini akan berakibat kebutuhan kolesterol dalam tubuh meningkat dan akibatnya kadar kolesterol dalam darah akan berkurang (15).

Penelitian lain menunjukkan bahwa penurunan kolesterol karena senyawa yang dihasilkan seperti asam-asam lemak rantai pendek dari proses fermentasi oleh bakteri asam laktat berkompetisi dengan HMG CoA untuk berikatan dengan enzim HMG CoA reduktase, sehingga sintesis kolesterol akan terhambat (17). Salah satu asam lemak rantai pendek hasil fermentasi yang memiliki pengaruh terhadap kadar kolesterol yaitu propionat. Propionat dapat menghambat inkorporasi asetat menuju triasilgliserol plasma dan juga cenderung menghambat inkorporasi asetat menuju plasma kolesterol. Hal ini akan berakibat pada menurunnya sintesis kolesterol karena asetat merupakan prekusor dalam pembentukan kolesterol (15).

Komponen zat gizi dan bioaktif dalam kedelai hitam pada produk black soyghurt juga mempengaruhi kadar profil lipid terutama penurunan kadar LDL seperti yang terjadi pada penelitian ini. Komponen tersebut di antaranya protein, serat, 
vitamin, asam lemak tidak jenuh, isoflavon, dan flavonoid (7). Komponen peptida utama pada protein kedelai adalah $\beta$-conglycinin atau $7 S$ globulin, dan glycinin atau $11 S$ globulin. Efek dari fraksi peptida ini hampir mirip dengan mekanisme penurunan kadar kolesterol oleh komponen kedelai lain yang tidak dicerna tubuh seperti serat melalui peningkatan sekresi asam empedu dan penghambatan absorbsi kolesterol yang diasup dari makanan. Selain itu, peptida ini dapat meningkatkan aktivitas reseptor LDL dan mendegradasi LDL di sel hepar. Hal ini akan berakibat pada menurunnya kadar LDL dalam serum (18).

Komponen penting lainnya dalam kedelai yang berpengaruh terhadap penurunan kadar kolesterol adalah isoflavon. Sebuah metaanalisis menemukan bahwa kandungan isoflavon yang tinggi pada asupan makanan dapat menurunkan serum LDL kolesterol. Isoflavon yang terkandung dalam kedelai merupakan sterol yang berasal dari tumbuhan (fitosterol) yang jika dikonsumsi dapat menghambat absorbsi dari kolesterol, baik yang berasal dari diet maupun kolesterol yang diproduksi oleh hepar. Hambatan ini terjadi karena fitosterol ini berkompetisi dan menggantikan posisi kolesterol dalam misel. Dengan adanya mekanisme tersebut, kolesterol yang terserap oleh usus juga sedikit sehingga pembentukan kilomikron dan VLDL (very low density lipoprotein) juga terhambat mengakibatkan kadar LDL serum juga akan turun (19).

Zat bioaktif lain yang dimungkinkan memiliki peran dalam menurunkan kadar kolesterol pada penelitian ini adalah antosianin. Antosianin merupakan sejenis flavonoid yang merupakan komponen utama warna hitam pada kedelai bahan baku pembuatan black soyghurt. Mekanisme penurunan kadar lipid pada hewan coba akibat konsumsi flavonoid disebabkan oleh beberapa faktor. Faktor tersebut antara lain penghambatan penyerapan kolesterol dan peningkatan ekskresi empedu (20). Selain itu, flavonoid juga mampu menghambat aktivitas enzim 3-hidroksi-3-metilglutaril CoA yang berperan dalam penghambatan sintesis kolesterol serta enzim acylCoA: Cholesteryl aciltransferase yang berperan dalam penurunan esterifikasi kolesterol pada usus dan hati. Selain itu, flavonoid juga mampu mengikat LDL kolesterol akibat sifat flavonoid yang lipofilik (21).

Salah satu mekanisme yang dapat meningkatkan kadar HDL adalah melalui peningkatan jumlah apolipoprotein A-1 yang merupakan prekusor pembentukan HDL. Akan tetapi, pada penelitian ini black soyghurt tidak dapat meningkatkan kadar HDL secara signifikan $(p>0,05)$. Hal ini sesuai dengan hasil penelitian lain yang menunjukkan pengaruh bakteri asam laktat dan kedelai terhadap kadar HDL yang hasilnya tidak signifikan. Hal ini dimungkinkan karena kolesterol HDL kadarnya di dalam serum lebih dipengaruhi oleh faktor genetik (familial) sebesar $50 \%$ dan sisanya dipengaruhi oleh faktor lain (22). Sebuah metaanalisis terhadap 38 uji klinis terkait pengaruh kedelai terhadap kadar HDL menunjukkan hasil yang tidak konsisten antar penelitian sehingga belum dapat disimpulkan bahwa kedelai dapat meningkatkan kadar HDL (6).

Pada peneitian ini tidak terjadi penurunan bermakna rasio LDL/HDL pada setiap kelompok perlakuan. Penurunan kadar LDL yang tidak disertai dengan peningkatan kadar HDL mengakibatkan penurunan rasio yang tidak signifikan sebagai indikator ketidakseimbangan kadar kolesterol di dalam tubuh (23). National Cholesterol Education Program (NCEP) merekomendasikan rasio LDL/ HDL sekitar 2,5. Pada penelitian lain dengan subjek 15.000 laki-laki berumur 40-84 tahun menunjukkan bahwa peningkatan 1 unit rasio LDL/ HDL berhubungan dengan meningkatnya risiko myocardial infarction (MI) sebesar 53\%. Kematian akibat penyakit jantung koroner terjadi ketika rasio LDL/HDL mencapai nilai antara 3,7-4,3. Pada penelitian ini menunjukkan bahwa yoghurt kedelai hitam mampu menurunkan rasio LDL/HDL pada tikus hiperkolesterolemia meskipun tidak signifikan. Kondisi ini dimungkinkan akibat respon yoghurt kedelai hitam yang beragam terhadap kadar HDL.

Masih terdapat keterbatasan pada penelitian ini salah satunya adalah tidak dilakukannya analisis zat bioaktif terlebih dahulu pada produk black soyghurt. Hal ini akan berakibat pada tidak diketahuinya jumlah komponen zat bioaktif yang dimungkinkan berperan dalam penurunan kadar kolesterol LDL pada penelitian ini. 


\section{KESIMPULAN DAN SARAN}

Pemberian black soyghurt pada tikus hiperkolesterolemia selama 21 hari mampu menurunkan kadar LDL secara signifikan pada dosis $4 \mathrm{~mL} / \mathrm{hari}$, akan tetapi tidak berpengaruh signifikan terhadap kolesterol HDL. Intervensi ini belum mampu menurunkan rasio LDL/HDL secara bermakna.

Perlu pengkajian lebih lanjut terkait pengaruh black soyghurt terhadap kadar HDL, mengingat lipoprotein ini merupakan faktor protektif terhadap atherosklerosis yang merupakan penyebab terjadinya penyakit kardiovaskuler. Selain itu, perlu dirintis uji pemberian black soyghurt pada manusia, karena dapat menjadi alternatif diet pada penderita hiperkolesterolemia yang relatif murah dan aman.

\section{RUJUKAN}

1. Kretchmer N, Zimmermann M. Developmental nutrition. Needham Heights: Allyn \& Bacon; 1997.

2. Hanafiah A, Karyadi D, Lukito WM, Supari $F$. Desirable intakes of polyunsaturated fatty acids in Indonesian adults. Asia Pac J Clin Nutr. 2007;16(4):632-40.

3. Krummel D. Medical nutrition therapy in cardiovascular disease. In: Mahan LK, EscottStump S, 11th ed. editors. Krause's food nutrition and diet therapy., editor. Philadelphia: Elsevier; 2004.

4. Mayes P. Sintesis, pengangkutan, dan ekskresi kolesterol. Biokimia harper, editor. Jakarta: Penerbit Buku Kedokteran EGC; 2004.

5. Wong W, Smith E, Stuff J, Hachey D, Heird $\mathrm{W}$, Pownell H. Cholesterol-lowering effect of soy protein in normocholesterolemic and hypercholesterolemic men. Am Soc Clin Nutr. 1998;68:138S - $9 S$.

6. Anderson J, Johnstone B, Cook-Newell M. Metaanalysis of the effects of soy protein intake on serum lipids. N Engl J Med. 1995;333:276-2.

7. Michihiro S. Soy in health and disease prevention. New York: Taylor and Francis Group; 2006.

8. Nuryati S. Aktivitas antioksidan dan daya terima minuman probiotik kedelai hitam (Glycine soja). Universitas Diponegoro Semarang; 2010.
9. James A, Stanley G. Effect of fermented milk (yoghurt) containing Lactobacillus acidophilus L1 on serum cholesterol in hypercholesterolemic humans. J Am Coll Nutr. 1999;18(1):43-0.

10. World Health Organization (WHO). General guidelines for methodologies on research and evaluation of traditional medicine. Geneva: WHO; 2001.

11. Anwar T, Linda E, Lawrence K, Eva L, Vlad V, Ruby J, et al. Interrelation of saturated fat, trans fat, alcohol intake, and subclinical atherosclerosis. Am J Clin Nutr. 2008;87:168-74.

12. Soeharto I. Serangan jantung dan stroke. Jakarta: Gramedia Pustaka Utama; 2004.

13. Maryanto S, Muis S. Pengaruh pemberian jambu biji (Psidium guajava $L$ ) pada lipid serum tikus (Sprague dawley) hiperkolesterolemi. MMI. 2004;39(2):105-11.

14. Suarsana I. Pengaruh yoghurt terhadap kolesterol total dan profil lipoprotein serum kelinci (studi pendahuluan) [Internet]. 2004. Available from: / arcchives/category/juet - vol - 5(1)-2004/-18k

15. Marie P, Edward R, Peter J. Consumption of fermented and nonfermented dairy products: Effects on cholesterol concentrations and metabolism. Am J Clin Nutr. 2000;71:674-81.

16. Winarti S. Seleksi bakteri asam laktat isolat ASI yang berpotensi menurunkan kolesterol secara in vitro. Institut Pertanian Bogor; 2011.

17. Hardiningsih R, Nurhidayat N. Pengaruh pemberian pakan hiperkolesterolemia terhadap bobot badan tikus putih wistar yang diberi bakteri asam laktat. BIODIVERSITAS. 2006;7(2):127-0.

18. Adams M, Golden D, Franke A, Potter S, Smith $\mathrm{H}$, Anthony M. Dietary soy $\beta$-conglycinin (7S globulin) inhibits atherosclerosis in mice. J Nutr. 2004;134:511-6.

19. Hapsari A, Poernomo B, Dhamayanti Y. Perbandingan efek pemberian sari kedelai kuning dan hitam terhadap rasio kolesterol LDL/ HDL darah tikus putih (Rattus norvegicus) dengan diet tinggi lemak. Surabaya: FKH Universitas Airlangga; 2009.

20. Gorinstein S, Leontowicz $H$, Leontowicz $M$, Krzeminski R, Gralak M, Delgado-Licon E, et al. Changes in plasma lipid and antioxidant 
activity in rats as a result of naringin and red grapefruit supplementation. J Agric Food Chem. 2005;53:3223-8.

21. Fuhrman B, Aviram M. Flavonoids protect LDL from oxidation and attenuate atherosclerosis. Curr Opin Lipidol. 2001;12:41-8.

22. Moriyama T, Kishimoto K, Nagai K, Urade R, Ogawa T, Utsumi S. Soybean beta-conglycinin diet suppresses serum triglyceride levels in normal and genetically obese mice by induction of beta-oxidation, down regulation of fatty acid synthase, and inhibition of triglyceride absorption. Biosci Biotechnol Biochem. 2004;6(8):352-9.

23. Octifani S, Kusmiyati D. Pengaruh pemberian margarin terhadap rasio kolesterol LDL/HDL tikus Sparague dawley (Artikel Ilmiah). Semarang: FK Universitas Diponegoro; 2012. 